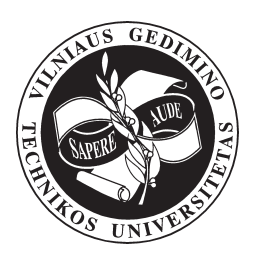

ISSN 1648-0627 print

ISSN 1822-4202 online

VERSLAS: TEORIJA IR PRAKTIKA

BUSINESS: THEORY AND PRACTICE

http://www.btp.vgtu.lt; http://www.btp.vgtu.It/en

2007, Vol VIII, No 2, 68-72

\title{
SUDE்TINGO REIŠKINIO STRUKTŪRIZUOTOS RODIKLIŲ SISTEMOS FORMAVIMAS
}

\author{
Romualdas Ginevičius \\ Vilniaus Gedimino technikos universitetas, Sauletekio al. 11, LT-10223 Vilnius, Lietuva \\ El.paštas romualdas.ginevicius@adm.vtu.lt
}

Iteikta 2007-01-08; priimta 2007-03-20

\begin{abstract}
Santrauka. Augant sudètingo reiškinio (SR) parametrams vis sunkiau tampa susekti ir ịvertinti jị apibendrinančių rodiklių tarpusavio ryšius. Ši aplinkybė apsunkina arba netgi padaro neimanomą rodiklių svorių nustatymą, pagristą ekspertiniais vertinimais. Be to, kyla klausimas, ar teisingas tvirtinimas, jog sudètingą reiškinį atspindintys rodikliai yra tarpusavyje susiję kaip vienos ir tos pačios sistemos elementai.

Išsamesnè analizė rodo, kad SR pavaizduoti galima tik hierarchiškai struktūrizuota rodiklių sistema. Ši sistema paaiškina, kaip, augant nagrinėjamo reiškinio parametrams, keičiasi rodiklių tarpusavio ryšiai: tiesioginė sąveika išlieka, bet tik tarp tų rodiklių, kurie pakliūna ì tą pačią jų grupę, apibūdinančią tam tikrą SR aspektą; tarp skirtingus aspektus apibūdinančių rodiklių išlieka netiesioginė priklausomybė, t. y. turime sąveiką, pasireiškiančią per tiesioginę, juos apibūdinančių agreguotų dydžių priklausomybę.

Straipsnyje pateikiamas SR rodiklių sistemos struktūrizavimas suteikia galimybę nustatyti jų svarbą, remiantis šių rodiklių tiesiogine tarpusavio sąveika.
\end{abstract}

Reikšminiai žodžiai: sudètingų reiškinių ir procesų kiekybinis įvertinimas, struktūrizavimas, rodiklių sistemos formavimas.

\section{GENERATING A STRUCTURED SYSTEM OF CRITERIA FOR DESCRIBING A COMPLICATED PHENOMENON}

\author{
Romualdas Ginevičius \\ Vilnius Gediminas Technical University, Sauletekio al. 11, LT-10223 Vilnius, Lithuania \\ E-mail: romualdas.ginevicius@adm.vtu.lt
}

Received 8 January 2007; accepted 20 March 2007

\begin{abstract}
When a phenomenon is getting complicated, acquiring more particular features or aspects, it is becoming more difficult to determine the relationships between the criteria describing it. In this case, it is hardly possible to determine the criteria weights based on expert evaluation. Moreover, the question arises if the statement that the criteria describing a complicated phenomenon are interrelated as the elements of a single system is true.

A comprehensive analysis shows that only hierarchically structured system of criteria can adequately describe a complicated phenomenon (CP). This system accounts for the variation of the criteria relationships, when the number of parameters of the phenomenon is growing. The direct relationship can be observed only between the criteria of the same set describing a particular CP aspect, while indirect relationship can be found between the criteria describing various $\mathrm{CP}$ aspects. This implies that there is a connection characterized by direct relationship between the aggregated magnitudes pertaining to the criteria considered.

The paper offers a method of structuring a system of CP criteria, allowing us to determine the significance of the criteria based on direct relationship between them.
\end{abstract}

Keywords: quantitative evaluation of complicated phenomena and processes, structuring, generating a set of criteria. 


\section{Ivadas}

Sudètingo reiškinio (SR) rodiklių sistemos formavimas yra vienas iš jo kiekybinio vertinimo etapu. Tikroveje jis pasireiškia daugeliu aspektų, savybių ir pan. Kita vertus, kiekvienas šis aspektas ar savybė apibendrina vieną ir tą patị reiškinị kaip jų visumą [1].

Nè vieno SR, pavyzdžiui, šalies ir jos regionų ekonominè ir socialinè plètra, i̇monès komercinès veiklos efektyvumas, dèstytojo darbo efektyvumas ir pan., neịmanoma išreikšti vienu dydžiu, kadangi sunku rasti toki jo rodikli, kuris integruotų visus esminius pasireiškimo aspektus.

Teigiant, kad sudètingą reiškini padeda suvokti konkretūs jo aspektai ir savybès, išplaukiančios iš jo kaip visumos, konstatuojama, kad šiuos aspektus ar savybes atspindintys rodikliai yra tarpusavyje susiję kaip vienos ir tos pačios sistemos elementai [1]. Išsamesnè sudètingų reiškinių analizė rodo, kad šis ryšys nèra toks paprastas ir labai priklauso nuo nagrinejjamos sistemos dydžio. Jeigu ji yra nedidelè, tai pasireiškia ir suvokiama nedaugeliu aspektų ar savybių. Jiems apibūdinti reikia mažai rodiklių. Be to, nedideli nagrinejjamos sistemos parametrai rodo ir tai, kad ji mažiau kompleksiška, taigi ir aspektai ar savybės, kurie padeda ją suvokti, nèra tokie įvairūs, labiau tarpusavyje susiję. Glaudesnis bus ir juos atspindinčiu rodiklių ryšys. Tokioje situacijoje, prireikus nustatyti rodiklių svorius remiantis jų sąveika, ekspertams dideliu problemų nekyla, nes jie turi galimybę nagrinèti tiesiogini šių rodiklių poveiki SR arba tiesioginę jų tarpusavio priklausomybę [1].

Visiškai kitokia padètis yra, kai nagrinėjame didelị, kompleksini, reiškini, suvokiamą gausybe aspektų ir pasireiškimo formu. Kuo jis kompleksiškesnis, tuo įvairesni šie aspektai ar savybès, taigi tuo sunkiau suvokiami ryšiai tarp jų. Jeigu kiekvienas iš šių aspektų ar savybių savo ruožtu apibūdinamas mažesniu ar didesniu rodiklių skaičiumi, tai susekti ryši tarp šiu rodiklių iš viso neimanoma. Pavyzdžiui, mūsų šalies regionų ekonominè ir socialinè plètra išreiškiama 180 rodiklių, priklausančių ivvairiems jos pasireiškimo aspektams [2]. Pasižiūrẻję i šių rodiklių prasmę matome, kad kai kurių iš jų tarpusavyje susieti tiesiogiai neįmanoma. Jiems priklausytų nusikalstamumo, užterštumo rodikliai, pasèlių plotas, gimstamumas ir daugelis kitú. Taigi galima daryti išvada, kad, augant nagrinejjamo reiškinio dydžiui, taigi ir kompleksiškumui, galimybẻ suvokti ji apibūdinančių rodiklių tarpusavio sąveiką mažèja arba visai išnyksta. Kyla klausimas: ar tokiu atveju teisingas tvirtinimas, kad sudètingą reiškini kaip visumą nusakančios savybės ar formos bei jas išreiškiantys rodikliai yra tarpusavyje susiję, ar i juos galima žiūrèti kaip i vienos ir tos pačios sistemos, taigi tarpusavyje sąveikaujančius elementus [1]. Kyla dar vienas svarbus klausimas - kaip tokioje situacijoje formuoti SR kiekybinio vertinimo rodiklių sistema.

\section{Sudėtingo reiškinio struktūrizuotos rodiklių sistemos formavimo galimybès}

Sudètingas, kompleksiškas reiškinys nuo ne tokio sudetingo, taigi ir ne tokio kompleksiško, skiriasi tuo, kad jis apima daugiau aspektu, kurie atspindi vis labiau besiskiriančias viena nuo kitos jo savybes. Kuo tokių savybiu daugiau ir kuo skirtingesnès jos yra, tuo silpnesnis tiesioginis ryšys tarp jų.

Tai panašu i vandens ratilus - kuo toliau jie nutolsta nuo židinio, tuo mažiau jie ryškūs, tuo sunkiau suvokti ryši tarp ratilo ir židinio. Jeigu jie labai nutolsta, ší ryši pamatyti iš viso neịmanoma, taigi netgi neaišku, kuriam židiniui jie priklauso.

Taigi, kai nagrinejjamasis reiškinys yra gana didelis ir sudètingas, tai svarbiausiu uždaviniu tampa ne ieškoti ryšių tarp jị apibūdinančių visų rodikliu, o rodiklius grupuoti pagal tam tikrus požymius [3]. Kitaip tariant, SR išskaidomas i „židinius“ (aspektus) ir formuojamos jiems priklausančių rodikliu sąrankos. Šio žingsnio būtinumas ir logika išplaukia iš samprotavimo, kad kuo rodiklis mažiau atspindi kažkokị nagrinejjamo reiškinio aspektą, taigi kuo toliau jis savo prasme nutolęs nuo šio aspekto esmès, tuo labiau jis atspindi kitą reiškinio aspektą. Jeigu jis nėra artimas jokiam nagrinèjamo reiškinio aspektui, vadinasi, jis pats yra vienas iš šių aspektú. Iš to išplaukia, kad sudètingą reiškini atspindinti rodiklių sistema negali būti vieno lygmens, nes grupavimas pagal tam tikrus požymius veda prie hierarchinès struktūros formavimo [3].

Pavaizdavus SR atspindinčius rodiklius hierarchine struktūra, galima paaiškinti sąveikos tarp jų pokyčio kitimą, augant jo parametrams. Dalis grupuojamų rodiklių priklausys gana skirtingas reiškinio puses nusakantiems aspektams. Tokiu atveju tiesioginè priklausomybė liks tik tarp rodiklių, apibūdinančių vieną ir tą pati aspektą, t. y. priklausančių tai pačiai grupei. Su rodikliais, tiesiogiai apibūdinančiais kitą reiškinio aspektą, jie jau bus susiję netiesiogiai, t. y. per aspektų rodiklius agreguojančius dydžius, kurie bus susiję tiesiogiai.

Visą šį mechanizmą paaiškinsime pavyzdžiu. Šalies regionų ekonominę ir socialinę plètrą apibūdinančius rodiklius galima suskirstyti i dvi dideles grupes - ekonominès plètros rodikliai ir socialinès plètros rodikliai. Pirmieji tarpusavyje bus susiję tiesiogiai. Ta pati galima pasakyti ir apie socialinès plètros rodiklius. O pirmosios grupès rodikliai su antrosios grupès rodikliais bus susiję jau netolygiai per tiesiogiai susijusius ekonominès ir socialinès plètros rodiklius agreguojančius dydžius (1 pav.).

1 pav. iliustruoja minti, kaip, augant nagrinejjamo reiškinio parametrams, kinta jo rodiklių tarpusavio sąveika: dalies rodiklių tiesioginiai ryšiai virsta netiesioginiais. Šiame paveiksle pavaizduota šalies regionų ekonominès ir socialinès plètros rodiklių hierarchinè struktūra yra neišsami, kadangi tiek ekonominè, tiek socialinè plètra savo 


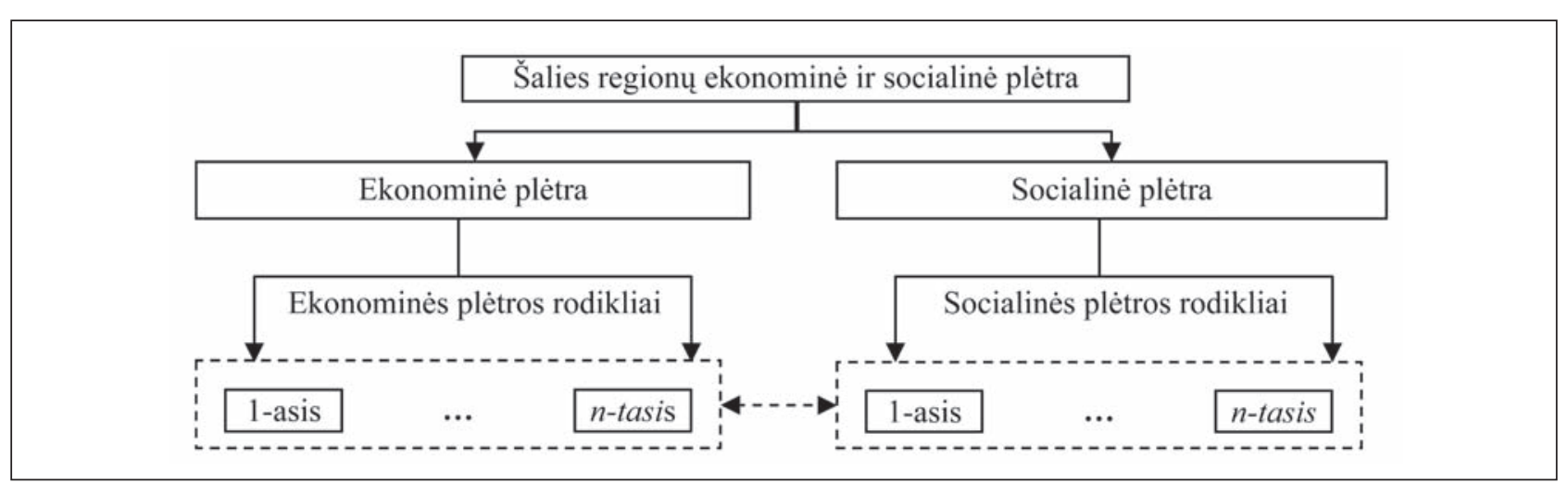

1 pav. Sudètingo reiškinio rodiklių tarpusavio ryšių pobūdis $(\longleftrightarrow-$ tiesioginis ryšys, $\longleftrightarrow--->-$ netiesioginis ryšys)

Fig 1. The type of interrelationship between the criteria describing a complicated phenomenon $(\longleftrightarrow-$ direct relationship, $<--->-$ indirect relationship)

ruožtu apibūdinama daugeliu aspektų. Tarp šių aspektų turètų pasiskirstyti visi ekonominę ir socialinę plètrą apibūdinantys rodikliai.

Gilinant rodiklių sistemos struktūrizavimą, t. y. ivvedant naujus hierarchinius lygmenis, gali pasirodyti, kad tam tikri agreguoti dydžiai irgi susieti tik netiesiogine priklausomybe, kadangi jie yra aukštesnio lygmens agreguotų dydžiu rodikliai. Tokiu atveju tiesiogiai priklausomi bus minèto aukštesnio lygmens agreguoti dydžiai.

Dabar galima pateikti SR hierarchiškai struktūrizuotą rodiklių sistemos formavimo tvarką. Visų pirma sudaromas nagrinėjamo reiškinio rodiklių sąrašas. Juo vadovau- jantis ir remiantis [4] siūloma metodika, sudaroma rodiklių sistema. Paskui prasideda rodikliu priskyrimas giminingoms grupėms. Jose atsiduria rodikliai, nusakantys SR aspektus ar savybes. Toliau vyksta šiu grupių integravimas i stambesnius darinius. Hierarchinès struktūros formavimo procesas baigiasi tada, kai, eilini kartą sujungus vis stambesnius dydžius, gaunamas vienintelis, kurio pavadinimas sutampa su nagrinèjamo reiškinio pavadinimu.

Visą ši procesą iliustruosime pavyzdžiu. Sudarysime Lietuvos apskričių aplinkos rodiklių hierarchinę struktūrą, tinkamą kiekybiniam ịvertinimui [3]. Statistikos departamento metraštis [2] pateikia 24 tokius rodiklius (žr. lentelę).

Lietuvos apskričių aplinkos rodikliai

The criteria describing the environmental conditions in Lithuanian regions

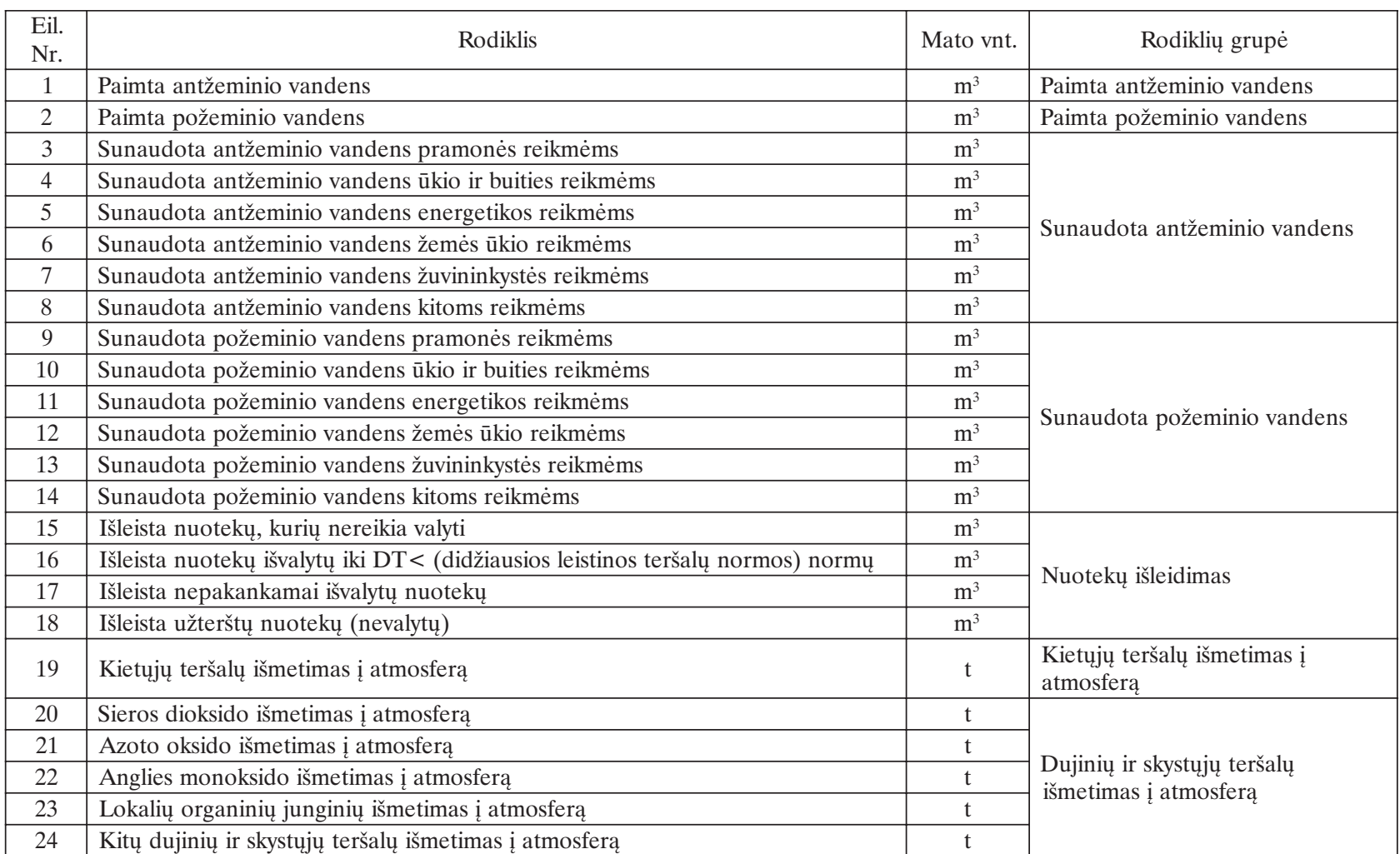




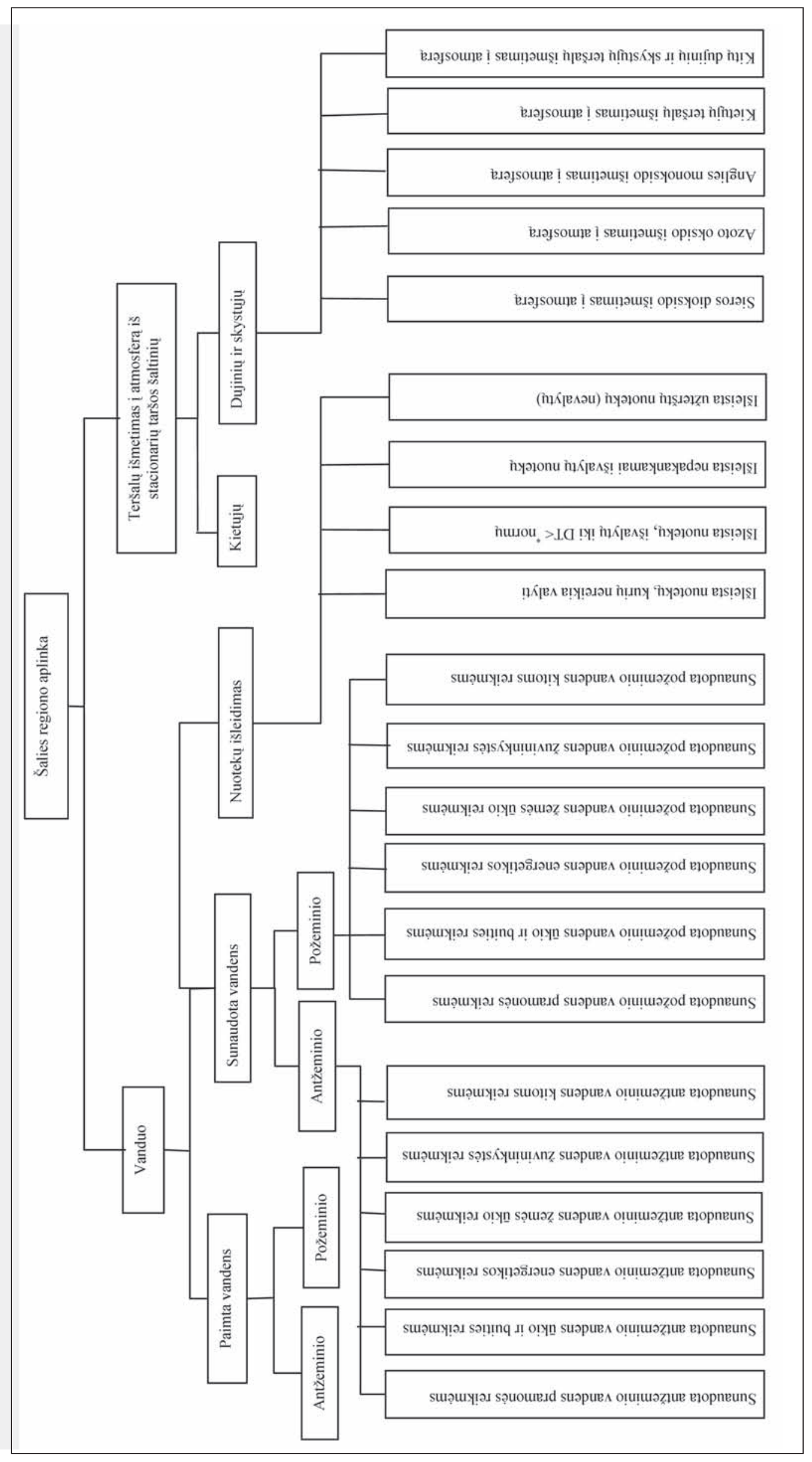

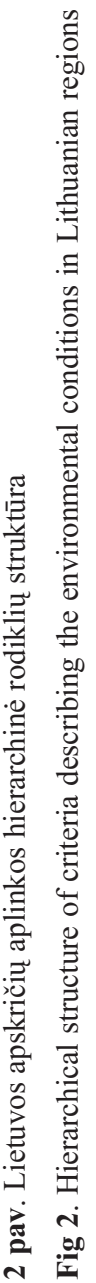


Visus juos pagal savo prigimti galima suskirstyti i septynias grupes. Kiekviena ši grupe atspindi tam tikrą nagrinejjamo reiškinio, aplinkos aspektą. Kaip matome iš lentelès, kai kurių grupių pavadinimas sutampa su rodiklio pavadinimu. Tokiu atveju grupeje yra tik vienas rodiklis, kadangi jis nèra artimas jokiam kitam nagrinèjamo reiškinio aspektui. Kitose grupèse rodiklių skaičius nėra didelis, todèl gali kilti noras grupių skaičių sumažinti ir tokiu būdu supaprastinti hierarchinę rodiklių struktūrą. Tačiau tokiu atveju vienoje grupeje arba šiu grupių junginyje atsidurtų gana priešingi savo prigimtims rodikliai. Turètume situaciją, kai rodiklių skaičiaus sąlygą atitinkančią grupe nagrinejjantys ekspertai vertintu priešingus savo prigimčiai rodiklius. Tai paveiktų vertinimo tikslumą. Todèl, formuojant rodiklių grupes ar jų grupių junginius, pirmenybę reikètų vis dèlto teikti ne jų skaičiui, o prigimčiai, bendrumui [3] Visą tai ivertinus gauta Lietuvos apskričiu aplinkos hierarchinè rodiklių struktūra (2 pav.).

Rodiklių sistemos struktūrizavimas sudaro galimybę nustatyti ju poveikį nagrinejjamam reiškiniui, remiantis tiesiogine šių rodiklių tarpusavio sąveika [1, 5-7]. Šiuo atveju ekspertai nustatys kiekvieno žemiausio lygmens rodiklių grupès svorius. Po to, paėmus rodikliu reikšmes ir taikant pasirinktus daugiakriterinio vertinimo būdus, bus nustatytos šiuos rodiklius jungiančių dydžių reikšmès. Tokiu procedūrų skaičius priklausys nuo rodiklių sistemos hierarchinių lygių skaičiaus [8].

\section{Išvados}

Augant nagrinėjamo reiškinio parametrams, vis sunkiau tampa susekti ji apibūdinančių rodiklių tarpusavio ryšius. Ši aplinkybė apsunkina rodiklių svorių nustatymą, pagrisstą ekspertiniais metodais. Be to, kyla klausimas, ar teisingas tvirtinimas, jog visi sudètingo reiškinio rodikliai yra tarpusavyje susiję kaip vienos ir tos pačios sistemos elementai.

Tyrimai rodo, kad sudètingą reiškinị apibūdinti gali tik hierarchiškai struktūrizuota rodiklių sistema. Kuo kompleksiškesnis nagrinejjamasis reiškinys, tuo daugiau ịvairesnių rodiklių reikia jam apibūdinti, tuo labiau struktūrizuota išeina ji atspindinti rodikliu sistema.

Suformuota sudètingo reiškinio struktūrizuota rodiklių sistema paaiškina, kokiu būdu pasikeičia jų tarpusavio ryšiai: tiesioginė sąveika išlieka tik tarp tų rodiklių, kurie pakliūva ì tą pačią grupę, apibūdinančią tam tikrą reiškinio aspektą; tarp skirtingus aspektus apibūdinančių rodiklių išlieka netiesioginė priklausomybè, t. y. sąveika, pasireiškianti per tiesioginę juos jungiančių agreguotų dydžiu priklausomybę.

Rodiklių sistemos struktūrizavimas suteikia galimybę nustatyti ju poveikị nagrinèjamam reiškiniui, remiantis tiesiogine šių rodiklių tarpusavio sąveika.

\section{Literatūra}

1. GINEVIČIUS, R. Daugiakriterinio vertinimo rodiklių svorių nustatymas remiantis jų tarpusavio sąveika. Verslas: teorija ir praktika, 2006, t. 7, Nr. 1, p. 4-13.

2. Lietuvos apskritys: ekonomine ir socialinè raida. Statistikos departamentas prie Lietuvos Respublikos Vyriausybès, 2006.

3. GINEVIČIUS, R. Procesų ir reiškinių hierarchinis struktūrizavimas. Verslas: teorija ir praktika, 2007, t. 8, Nr. 1, p. 14 18.

4. GINEVIČIUS, R.; PODVEZKO, V. Daugiakriterinio vertinimo rodikliu sistemos formavimas. Verslas: teorija ir praktika, 2005, t. 6, Nr. 4, p. 199-207.

5. SAATY, T. L. The Analytic Hierarchy Process. M. Graw-Hill, New York, 1980.

6. SAATY, T. L.; KEARAS, K. P. Analytical Fanning: Hie organization ot Systems. Pergamon Press, Oxford-New YorkToronto-Sydnly-Frankfurt, 1982.

7. SAATY, T. L. Fundamentals of Decision Making and Priority Theory with the AHP. RWS Publication, Pittsburgh, PA, USA, 1994.

8. ГИНЯВИЧЮС, Р.; ПОДВЕЗКО, В.; МИКЯЛИС, Д. Система оценки социально-экономического развития регионов. In Polityka rozwoju Europy Środkowo-Wschodniej: Aspekty makroekonomiczne i regionalne. Wloclawek: Wloclawskie Towarzystwo Naykowe, 2006, p. 211-224.

Romualdas GINEVIČIUS. Doctor Habil, Professor. Rector of Vilnius Gediminas Technical University (VGTU), Saulètekio al. 11, LT-10223 Vilnius, Lithuania.

A graduate of Vilnius Gediminas Technical University (former Vilnius Civil Engineering Institute) engineering economy (1969), Doctor (1975). Doctor Habil (1997, VGTU). Author of 10 books, monographs, about 150 research articles published in Lithuania and abroad. Member of International Academy of Information. Research interests: market, economy, theory of organizations. 